\title{
1. Introduction to international human rights law and diplomacy
}

International human rights law (IHRL) is a body of legal norms, not moral or political obligations, ${ }^{1}$ regulating human rights among nation States. IHRL and diplomacy are intertwined as States manoeuvre in international forums to achieve their goals with respect to human rights.

'Diplomacy' connotes the application of intelligence and tact to the conduct of official relations and execution of foreign policies between governments of nation States by peaceful means, applying persuasion and different forms of pressure, the success of which depends, to a great extent, on the power behind them. The power may be hard power, such as military and economic might, or soft power founded on the ability of one State or government to shape the preferences of others by co-opting instead of coercing them to agree because they appreciate its values, emulate its example and/or aspire to its level of prosperity and openness, for example. ${ }^{2}$ There are two dimensions of diplomacy - bilateral and multilateral. Bilateral diplomacy involves interaction between two nation States, whereas multilateral diplomacy is diplomatic intercourse in international forums, such as the United Nations (UN), among States that are members of the respective forums, where they join together as groups or blocs to enhance their negotiating power and, in some cases, to get recognition of belonging to a specific group or bloc.

The UN is the world's largest, all-inclusive multilateral diplomatic forum. Within the UN system States are divided into five regional groups for the purpose of equitable geographical allocation of seats or positions: the African Group; the Asia-Pacific Group, which, strangely, includes Cyprus; the Eastern European Group; the Latin American and Caribbean Group (GRULAC); and the Western European and Others Group (WEOG), which includes the USA, Canada, Australia, New Zealand and Turkey. Beyond the aforesaid regional groups there exist numerous groupings. The Council of Europe $(\mathrm{CoE})$, set up

1 Hurst Hannum, 'Reinvigorating Human Rights for the Twenty-First Century' (2016) 16 Hum Rts L Rev 409, 411, 446-51. See for the difference between ethics or moral rights and law, Amartya Sen, The Idea of Justice (Penguin 2010) 361-5.

2 Ivor Roberts (ed.), Satow's Diplomatic Practice (7th edn, OUP 2017) 3-4 and n. 2. 
in 1949 to uphold human rights, democracy and the rule of law in Europe, has 47 Member States, including all the 28 Members of the European Union (EU) and all Eastern European States except Belarus. The Organisation of Islamic Cooperation (OIC), founded in 1969 to be the voice of the Islamic world, consists of 57 Muslim-majority States, including Albania, Azerbaijan and Turkey, which are CoE Member States. The League of Arab States, or the Arab League, set up in 1945, now comprises 22 Member States, all of which are also members of the OIC and ten of which are situated in Africa and are members of the African Union. The majority of Muslim-majority States today fall somewhere between 'purist' Saudi Arabia and 'secular' Turkey. ${ }^{3}$ The other two important groupings are the Group of 77 (or G77, comprising 134 developing States including China) and the Non-Aligned Movement (NAM) consisting of 120 Member States that are, in theory, not formally aligned with or against any major power bloc.

According to Thomas Buergenthal, a former judge president of the Inter-American Court of Human Rights and a former judge of the International Court of Justice (ICJ), '[t] he greatest weakness of the United Nations human rights system is its susceptibility to politicization'. ${ }^{4}$

The terminology 'politics' derives from the fourth-century BC Greek philosopher Aristotle's work on affairs of the 'cities' or polis in Greek. ${ }^{5}$ The Collins English Dictionary gives the modern meaning of 'politics' as 'the actions or activities concerned with achieving and using power in a country or society'. Human rights are themselves the outcome of politics in several ways. To begin with, the process of characterizing something as a right is a political one. So is the finding of the conditional exceptions to the application of certain rights. This is also the case regarding the balancing of competing rights claims. ${ }^{6}$ For example, a decision to construct a giant dam for electricity generation to realize the right to development of one group also dislodges the

\footnotetext{
3 Mashood A Baderin, International Human Rights and Islamic Law (OUP 2003) 8.

'A Brief History of International Human Rights Law', UN Codification Division, Office of Legal Affairs, Audiovisual Library of International Law, http://legal.un.org/ avl/1s/Buergenthal_HR_video_1.html, accessed 11 Aug 2019.

Aristotle, The Politics of Aristotle (Benjamin Jowett tr, Clarendon Press 1885).

6 Martti Koskenniemi, The Politics of International Law (Hart 2011) 157-9; Elena Katselli, 'The Rule of Law and the Role of Human Rights in Contemporary International Law' in Rob Dickinson, Elena Katselli, Colin Murray and Ole W Pedersen (eds), Examining Critical Perspectives on Human Rights (CUP 2012) 131, 144-6; Jack Donnelly, International Human Rights (3rd edn, Westview Press 2007) $3-9$.
} 
right and freedom of individuals who live and earn their living on the land to be permanently submerged under the dam's water. ${ }^{7}$

IHRL forms part of international law, which is, to a large extent, the effect of politics involving prejudice and bias as practised by States. ${ }^{8}$ IHRL is also part of international relations and hence international politics, particularly when some States claim justifications for human rights in other States with ulterior motives not actually related to human rights but to some kind of political gains. ${ }^{9}$ Moreover, when it comes to the implementation and enforcement of human rights, the realpolitik of international relations cannot be disregarded. ${ }^{10}$

The ICJ, the UN's principal dispute settlement organ, has recognized on several occasions that questions submitted to it may also have political aspects which arise in international life. However, whatever its political aspects, the ICJ 'cannot refuse to admit the legal character of a question which invites it to discharge an essentially judicial task, namely, an assessment of the legality of the possible conduct of States with regard to the obligations imposed upon them by international law'. ${ }^{11}$ Likewise, the fact that IHRL may also have political aspects does not deprive IHRL of its legal character requiring compliance by the States legally bound by this law.

In IHRL, as in any other field of international law, it is the nation State that has 'international legal personality' to act on the international plane, with individuals within the State as beneficiaries of such acts by the State. ${ }^{12}$ It is unacceptable nowadays for nation States to assert sovereignty in defence of egregious human rights violations. ${ }^{13}$

Domestically, the government in each nation State needs to convince its citizens that they are not treated worse than their counterparts elsewhere;

7 See, generally, Bas de Gaay Fortman, Political Economy of Human Rights: Rights, Realities and Realization (Routledge 2011).

8 Corfu Channel (United Kingdom v Albania) Judgment [1949] ICJ Rep 4, 41 (Separate Opinion of Judge Alvarez); Koskenniemi, The Politics of International Law v-vi; Rein Müllerson, 'Ideology, Politics and International Law' (2016) 15 Chinese JIL 47; Tanja Aalberts and Thomas Gammeltoft-Hansen, The Changing Practices of International Law (CUP 2018) 26.

9 Cf Michael Goodhart, 'Introduction: Rights in Politics and Practice' in Michael Goodhart (ed.), Human Rights: Politics and Practice (3rd edn, OUP 2016) 1, 5.

10 Frans Viljoen, International Human Rights Law in Africa (2nd edn, OUP 2012) $40-41$.

${ }_{11}$ Legality of the Threat or Use of Nuclear Weapons, Advisory Opinion [1996] ICJ Rep 226, 233-4 [13] and the cases cited therein.

12 Robert Jennings and Arthur Watts (eds), Oppenheim's International Law (9th edn, OUP 2008) i (Peace) ch. 2; James Crawford, Brownlie's Principles of Public International Law (8th edn, OUP 2012) 115.

13 Beth A Simmons, Mobilizing for Human Rights: International Law in Domestic Politics (CUP 2009) 3, 27. 
or else popular discontent may unseat the government or regime in power. Internationally, every State has to defend, either on its own or in cooperation with some other States, its domestic human rights record and avert potential censure by some other States that will make it an international outcast and sow the seeds of discontent among its own population, as well as depriving it of the benefits ensuing from international trade, foreign investment and inbound tourism, among other things.

Government delegations of most States who are entrusted with human rights negotiations routinely face two unenviable assignments - one international, the other domestic. Internationally, they must try not to accept any change, imposed from abroad, to the status quo of the human rights situations at home. To this end, they must defend their State's human rights record, find allies to support their position and oppose or pre-empt any proposed change to that status quo. Domestically, after the said efforts partly or wholly fail, they must explain to their superiors at home why they fail and suggest the best possible solutions, such as becoming party to an international human rights treaty subject to reservations to the extent permissible by the treaty. Domestic resistance is to be expected from stakeholders with vested interests in maintaining the status quo and from ignorant and/or impassive actors who perceive no pressing reason to alter the status quo. Various actors, including victims of human rights violations, civil society and foreign governments, often join forces to persuade the State in question to progress in terms of human rights promotion and protection. Not infrequently, certain States take initiatives to forge ahead with progressive developments of new norms and higher standards of human rights, propelled by the maturity stage of human rights awareness, promotion and protection in these States. Also not infrequently, delegations sent by States to bilateral or multilateral human rights meetings comprise at least a few delegates who are humanistic thanks to their upbringing, education, personal experience, culture, religious belief, open-mindedness and so forth. They are 'agents of change' when they are back at home, abating the stubbornness of their State's resistance to human rights improvement as well as trying to alleviate the harshness of existing laws and measures of the State in the human rights field.

Ideally, human rights should be the rights of all persons irrespective of who or where they are, opposable against everyone and a legitimate concern of the international community. Above all, human rights should be upheld without double standards and be universal in time as well as a process..$^{14}$ But the real world is quite different.

14 Eva Brems, Human Rights: Universality and Diversity (Martinus Nijhoff 2001) 4, 12-15, 295, 307, 309-11. 
EU and WEOG Member States are the most united of all groups in their positions on human rights issues. Although Eastern European States are members of the CoE, which also includes all EU Member States, they are the least vocal of the $\mathrm{CoE}$ members, being willing to give importance to the context surrounding each of the human rights issues. NAM accords significance to the right to development. Beyond the aforesaid, the rest of the groupings are quite split, depending on the particular human rights issues in question, although most GRULAC Member States tend to be very pro-human rights. Russia is close to China, Cuba and several Member States of the G77 that are frequently subjected to international censure on human rights issues.

Diverging positions among States with regard to human rights may actually reflect the underlying fact that Homo sapiens, by nature, is physically different, inhabits different parts of the Earth and occupies different rungs of society - and the world's human citizens seem to be generally trapped in playing a 'social Darwinism' game of 'survival of the fittest' ${ }^{15}$ Each group of human beings tends to have a primordial instinct for its own betterment, often at the expense of other groups. In the era of nation States, each State protects its interests vis-à-vis another State. In a domestic society, one human being in a relatively superior or better-off position tends to treat not as an equal another human being in a relatively inferior or worse-off position. Phrased differently, the 'haves' tend to protect their personal interests against any encroachment by the 'have nots', the rulers against the ruled, and one religious belief or ethnicity or race or caste against another. Even in a State priding itself on upholding the human rights of its citizens, minorities are not generally or usually accorded parallel human rights protection and this has been the case for a long time. The situation is generally worse for migrants finding themselves in a foreign State. ${ }^{16}$ Some States face chronic national poverty that undermines their capability and willingness to protect human rights for the marginalized members of the society who happen to constitute the majority in that State. Civil wars, struggle for power to rule the nation, social instability that breeds suspicion among different groups within the nation and a legacy of past repression, with the powers-that-be striving to maintain the status quo even at the expense of those opposing it, are oft-cited causes for disregard of human rights. Although the nature of human rights abuses varies, mirroring the causes giving rise to

15 See Herbert Spencer, The Principles of Biology (William Norgate 1864) vol I, 144, basing his conclusion on Darwin's evolutionary theory (Charles Darwin, On the Origin of Species: By Means of Natural Selection, or the Preservation of Favoured Races in the Struggle for Life (John Murray 1859)).

16 Rosa Freedman, Failing to Protect: The UN and the Politicisation of Human Rights (C Hurst \& Co 2014) 79-85. 
the abuses in a particular nation and region of the world, ${ }^{17}$ studies of deliberate human rights repression within a nation State are consistent in their conclusion that the motivation and likelihood for the repression emanate from real or imagined threats to the regime governing the State and unchecked power of government authorities, respectively. ${ }^{18}$

Notwithstanding the above, there is a silver lining. An in-depth analysis of ethnographic records from 60 societies has led to the discovery of seven plausible candidates for universal moral rules as a collection of tools for cooperation that are shared by communities around the world. The seven plausible candidates for universal moral rules are: (1) helping family members, (2) helping group members, (3) engaging in reciprocal cooperation, (4) being brave, (5) respecting one's superiors, (6) being fair in sharing or dividing a disputed resource, and (7) respecting others' property. ${ }^{19}$ The challenge for IHRL is how to turn these universal moral values into tools for cooperation to improve human rights promotion and protection.

Given that humans are different in terms of, among other things, race, ethnicity, culture, traditions and religious beliefs, universal agreement on the specific contents of every human rights norm applicable in all contexts/ societies should not be expected. In fact, a reason for opposing human rights as propagated by a society or group is the perceived attitude of moral superiority and the condescending way that such society or group has been used in the past to justify colonialism, slavery and discrimination of the exploited peoples who are now the target of the human rights propagation. ${ }^{20}$ According to an Islamic legal scholar, most Muslim proponents of the view that Islam is incompatible with IHRL are not really opposed to IHRL as such, but are disappointed with and protest against Western hegemony/ideology as well as the alleged double standards practised by the West. ${ }^{21}$

Double standards are often referred to in the confrontation between the West and the rest of the world, as in the Chinese reaction in response to the accusation that China has arbitrarily detained two Canadian nationals to retaliate against the Canadian authorities' arrest of a Chinese national who is the chief finan-

17 Cf Sonia Cardenas, 'Human Rights in Comparative Politics' in Goodhart (ed.), Human Rights 77, 79, 81.

18 Kathryn Sikkink, Evidence for Hope: Making Human Rights Work in the 21st Century (Princeton University Press 2017) 186.

19 Oliver Scott Curry, Daniel Austin Mullins and Harvey Whitehouse, 'Is It Good to Cooperate? Testing the Theory of Morality-as-Cooperation in Sixty Societies' (2019) 60 Current Anthropology 49.

20 Brooke Ackerly, 'Feminist and Activist Approaches to Human Rights' in Goodhart (ed.), Human Rights 28, 29-32.

21 Baderin, International Human Rights and Islamic Law 15-16, 28. 
cial officer and daughter of the founder of the Chinese technology company Huawei. China considers it wrong that 'to some people, only Canadian citizens should be treated in a humanitarian manner and their freedom deemed valuable, while Chinese people do not deserve that', and that 'the laws of Canada or other Western countries are laws and must be observed, while China's laws are not and shouldn't be respected'. China questions whether 'a handful of Western countries really represent the whole international community'. It concludes: 'The reason why some people are used to arrogantly adopting double standards is due to Western egotism and white supremacy. In such a context, the rule of law is nothing but a tool for their political ends and a fig leaf for their practising hegemony in the international arena. ${ }^{22}$

Another outright rejection of the legitimacy of IHRL is based on the accusation that it is 'foreign or anti-national'. ${ }^{23}$

This book intends to deal with IHRL and diplomacy in peacetime; it therefore does not touch upon international humanitarian law applicable in armed conflicts, which is a separate discipline of international law subject to detailed discrete international regulations ${ }^{24}$ although historically humanity in war was a source of modern human rights law. ${ }^{25}$

IHRL cannot be completely separated from international criminal law. ${ }^{26}$ The latter is an offshoot of IHRL in the sense that IHRL gradually developed a criminal law arm to prosecute the worst human rights offenders. ${ }^{27}$ Gross

22 Lu Shaye (Ambassador of China to Canada), 'China ambassador: why the double standard on justice for Canadians, Chinese?' Hill Times (9 Jan 2019) https:// www.hilltimes.com/2019/01/09/double-standard-justice-canadians-chinese/182367, accessed 11 Jan 2019.

23 Sikkink, Evidence for Hope 12.

24 Contra: Hannum, 'Reinvigorating Human Rights for the Twenty-First Century' 424-5.

25 Gerd Oberleiter, 'Humanitarian Law as a Source of Human Rights Law' in Dinah Shelton (ed.), The Oxford Handbook of International Human Rights Law (OUP 2013) 274.

26 Cf the seemingly contrary view in Hannum, 'Reinvigorating Human Rights for the Twenty-First Century' 413-15, 419; Larissa van den Herik, 'Economic, Social and Cultural Rights: International Criminal Law's Blind Spot?' in Eibe Riedel, Gilles Giacca and Christophe Golay (eds), Economic, Social and Cultural Rights in International Law: Contemporary Issues and Challenges (OUP 2014) 343, 344-8, 365-6.

27 Ilias Bantekas and Lutz Oette, International Human Rights Law and Practice (2nd edn, CUP 2016) 682; Andrew Clapham, 'Human Rights and International Criminal Law' in William A Schabas (ed.), The Cambridge Companion to International Criminal Law (CUP 2016) 11, 11; Christian Tomuschat, Human Rights: Between Idealism and Realism (3rd edn, OUP 2014) ch. 18; Robert Cryer, 'International Criminal Law' in Daniel Moeckli, Sangeeta Shah and Sandesh Sivakumaran (eds), International Human Rights Law (3rd edn, OUP 2018) 521. Eric A Posner (Twilight of Human Rights Law 
human rights violations have come to be criminalized and prosecuted as international crimes under international criminal law. International criminal law is a vital international legal regime to ensure individual criminal accountability for serious human rights violations. ${ }^{28}$ Yet the relationship between IHRL and international criminal law is a complicated one as the latter needs to comply with applicable international human rights norms such as the principle of legality requiring that a person not be subject to criminal punishment except for an act that was criminalized by law before he/she perpetrated the act (nullum crimen sine lege), the right to a fair trial, the right to life, the due process of criminal justice and so on. ${ }^{29}$

After this brief introductory chapter, Chapter 2 will critically question the claim that IHRL enjoys universalism of recognition. Chapter 3 will analyse the operation of IHRL within the UN system, where idealism clashes with international politics and international law, while Chapter 4 will discuss the role of diplomacy vis-à-vis IHRL as applied within regional human rights mechanisms across the globe. Chapter 5 questions whether everyone is protected by the nine 'core' treaties monitored by the ten existing international human rights treaty bodies, including in view of the reservations made by States Parties to such treaties. This is followed, in Chapter 6, by looking at the compliance with and enforcement of IHRL. Chapter 7 will endeavour to find reconciliation and accommodation among different perspectives and notions regarding international human rights so that international human rights norms could be 'universalized'. The final Chapter 8 will then look at two new dimensions of IHRL - in cyberspace and at sea.

(OUP 2014) 52-3) considers the 'impulses' behind IHRL to have animated international criminal law as well although the latter pre-dates the former by centuries.

28 Aryeh Neier, The International Human Rights Movement: A History (Princeton University Press 2012) 258-84, 309-11.

29 Clapham, 'Human Rights and International Criminal Law' 11-15. 